Article

\title{
Application of GIS Tools in the Measurement Analysis of Urban Spatial Layouts Using the Square Grid Method
}

\author{
Lukasz Musiaka (D) and Marta Nalej *(D) \\ Faculty of Geographical Sciences, University of Lodz, Kopcińskiego 31, 90-142 Łódź, Poland; \\ lukasz.musiaka@geo.uni.lodz.pl \\ * Correspondence: marta.nalej@geo.uni.lodz.pl; Tel.: +48-426-35-45-68
}

Citation: Musiaka, Ł.; Nalej, M. Application of GIS Tools in the

Measurement Analysis of Urban Spatial Layouts Using the Square Grid Method. ISPRS Int. J. Geo-Inf. 2021, 10, 558. https://doi.org/ $10.3390 /$ ijgi10080558

Academic Editors: Motti Zohar and Wolfgang Kainz

Received: 13 July 2021

Accepted: 15 August 2021

Published: 17 August 2021

Publisher's Note: MDPI stays neutral with regard to jurisdictional claims in published maps and institutional affiliations.

Copyright: (c) 2021 by the authors. Licensee MDPI, Basel, Switzerland. This article is an open access article distributed under the terms and conditions of the Creative Commons Attribution (CC BY) license (https:// creativecommons.org/licenses/by/ $4.0 /)$.

\begin{abstract}
The principal aim of this paper is to present the capabilities of newly developed GIS tools for measurement analysis of urban spatial layouts, using the square grid method. The study of urban morphology and metrology is a multistage process, which involves the metrological analysis of town plans. The main research step is the determination of measurement modules of town layouts, using the square grid. By using GIS software, the authors developed a new tool, named HGIS Tools, which allow to create any number of modular grids with the selected cell size that corresponds to urban units of distance and surface area. When investigating a large number of towns and cities, this offers a significant improvement of the research procedure. The paper presents a test of the tool's potential on the example of regular medieval towns from the area of the former Teutonic Order state (currently the territory of Poland), diversified in terms of size, genesis and morphometrics. The obtained results confirmed that HGIS Tools allowed to determine the hypothetical measurement module of the layout of the cities studied. The results were consistent with the analyses of other authors carried out with the traditional grid-square methods. The test of the HGIS Tools showed their significant potential in conducting morphometric analyses of spatial arrangements of urban spatial layout on a larger scale.
\end{abstract}

Keywords: historical GIS; HGIS; GIS tools; fishnet; grid; urban morphology

\section{Introduction}

The purpose of this paper is to present the possible use of GIS tools for the measurement analysis of urban spatial layouts, using the square grid method. The functionality of tools available in the ArcMap application from ESRI is insufficient to conduct morphological and morphogenetic research. The authors had to create appropriate tools, using the Python programming language. The operational capabilities of the new tools were presented on examples of medieval towns of the Teutonic Order in Prussia (now in Poland): Nowy Staw, Elblag and Grudziądz. The main criterion for the selection of the research group was the regularity of spatial planning and similar period of origin and territorial vicinity, resulting from being located by the same investor-the State of the Teutonic Order. The article is an introduction to a study of the measurement of a larger group of cities in the area of former Prussia, and its main purpose is to present and test the tool.

Scientific studies of the origins and processes of the formation of the spatial layouts in towns and villages date back to the 19th century [1]. Today, the morphological and morphogenetic research of settlement unit is mostly conducted by geographers, architects, historians and art historians [2]. Morphological studies of the settlement are also the domain of archaeology [3,4]. Each of these disciplines uses its own research apparatus, which emphasizes the different methodological aspects and sources. Regardless of the methodology adopted, retrogressive investigation of spatial arrangements faces many difficulties. The main barriers include the shortcomings of the source base, both written and cartographic, which often forces the hypothetical nature of many analyses $[5,6]$. The common denominator of morphological and morphogenetic settlement research is 
the analysis of archival cartographic material [1,7-14]. However, we can be faced with numerous challenges when attempting to use archival maps and plans to obtain data concerning the spatial development of a given settlement unit in the past [15]. There can be also listed bad technical conditions and decreased legibility of archival documents, lack of carthometry or faithful mapping of the surface on a map plane, and the inaccuracy of archival cartography [5,16-19]. Metrological studies of modern base maps alone, not backed up by archaeological and architectural research, may lead to erroneous conclusions, due to the changing ownership divisions and development over the ages [20]. The process of 'town-plan analysis', which uses post-medieval cartography as a source from which to reconstruct medieval urban topographies, in contrast to the Conzenian school, is often criticized $[15,21]$. For these reasons, results based on cartographic sources have to be confronted with other data sources [2]. Analyses of non-cartographic sources conducted by historians and art historians are especially important here. For dozens of years now, the significance of archaeology and architecture in settlement research has been growing, as they serve to verify the assumptions and theories of both geographers and historians [22,23]. Therefore, it seems that the best results can be achieved by combining different research approaches with a critical analysis of the results obtained. Unfortunately, in practice, such studies are rare.

In urban morphogenetic and metrological research, the main aim is usually to find the roots of the form, to explain its genesis, and then to recreate its past development [24]. In morphological studies, the primary issue in the spatial research of urban layouts (measurement analysis) is the determination of modular rules for its measurement, and the discovery of the units of distance and area measurement used when plotting them in the field. The next stage in the metrological analysis is the search for the modular structure of field parcels, plots in urban settlements, urban blocks, building sites and other elements [25].

One of the methods used for metrological analyses of urban measurements is the square grid [25-31]. It is used as an auxiliary method when searching for modular divisions of a settlement, overlaying it on the layout under analysis [26,32]. The grid may be wellmatched or not. The grid has to be drawn over a copy of the town plan, using trial and error. To examine a larger group of towns, a whole set of grids of different gauges and scales could be drawn by hand. Slightly translucent paper or transparent film for back-lit projectors was used for this purpose. The results of the analysis, the chartered spatial layout within a grid of a certain gauge, was presented on a separate sheet. Figure 1 shows the use of a typical manual graph paper for that purpose. 


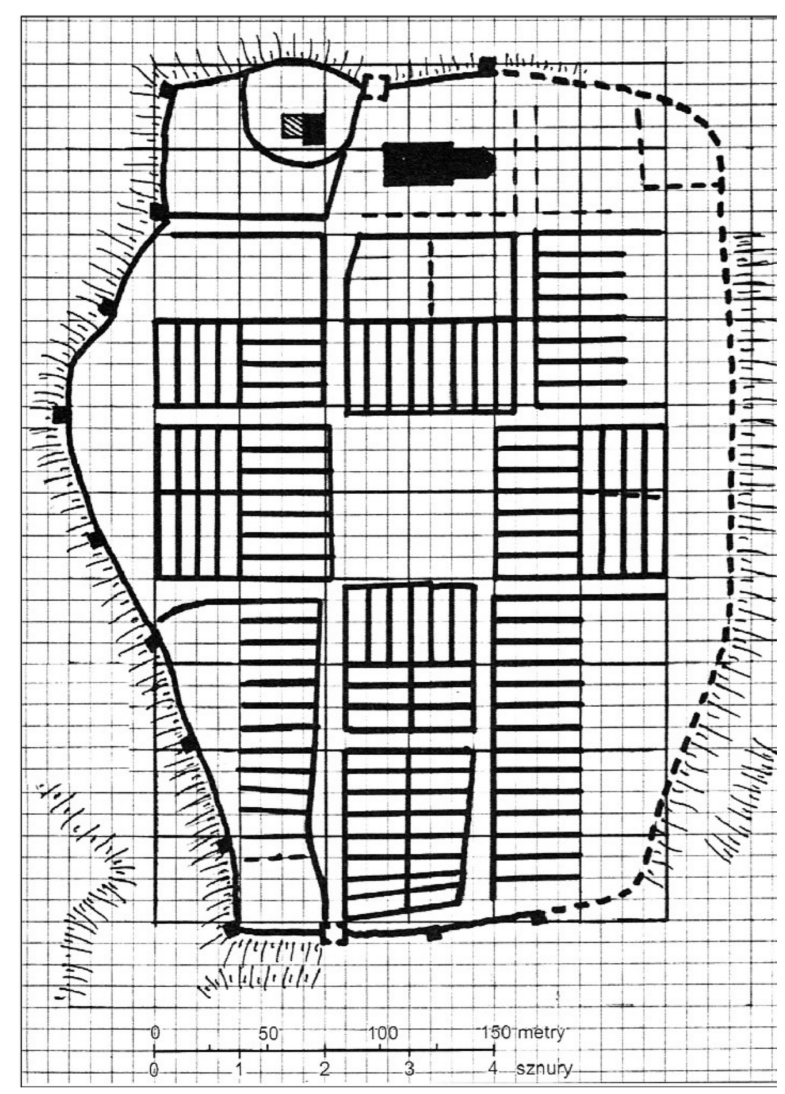

Figure 1. Hand-drawn sketch of the most important elements of the city layout on the background of the squares grid, example of Wieliczka [33].

By using a modular grid for a town plan and conducting detailed metrological measurements, the shapes, size and proportions of markets, as well as plots and urban blocks can be analyzed. Based on empirical research, the initial dimensions of urban plots used to determine the most widely used measuring modules in the city centers can be recreated. By focusing on the issues of sizes and proportions of cities, modular layout schemes can be created for groups of cities with common geographical and chronological scopes [34,35].

The medieval surveyors may have plotted a certain grid of squares in the field when initially measuring for the city. Alternatively, they could have used the tradition of ancient geometry $[25,34]$. Such a method is an excellent way to facilitate the spatial planning of a regular medieval city. Very rarely can we find almost perfectly geometric examples of chartered cities because the initial plan is deformed by terrain limitations, such as a bend in the river, a steep hill, previous buildings and roads, or ownership divisions [36]. New towns, founded on the 'raw root' (in cruda radice), or in previously uninhabited locations, had a better chance of having a regular grid of streets and blocks [1]. This method of simple medieval parceling allows us to overlay rod or rope grids and other dimensions onto the plans of different cities.

We can distinguish two types of grids: primary-actual measurements and a grid of essential elements of the urban layout-which facilitates the discovery of the composition idea behind the urban settlement, an analysis of the elements of layout of individual systems, such as the location of the market, the ratio between its size and the overall area of the city, as well as an analysis of the repeatability of market dimensions in other elements of the city. Additionally, it makes it easier to compare different planning concepts [25].

The progress in the computerization of research processes may facilitate the morphological and morphometrical studies of urban centers. Over the last twenty years, new spatial analysis methods have appeared, utilizing GIS tools, as well as spatial and historical tools-Historical Geographic Information Systems (Historical GIS or HGIS) [37-44]. New technologies allow for improvements of traditional research methods, introducing brand 
new data processing methods, and even expanding the current research perspectives. The application of GIS in studying the morphology and morphometry of settlements will surely not solve all methodological problems but may significantly facilitate analyses and create an opportunity to combine different approaches on a common plane.

The paper is organized as follows. The first section "Introduction" provides a brief overview of the traditional grid method used in urban morphology research. The next section, "Materials and Methods", describes the study area and presents the new HGIS Tools set. The "Results" section contains analysis of usefulness of HGIS Tools in morphological studies, which is presented based on studies of selected cities. The article closes with "Discussion" and "Conclusions", which summarize the possibility of using GIS tools for the analysis of historical urban layouts with the use of square grids.

\section{Materials and Methods}

\subsection{Study Area}

The examined towns of Elblag, Grudziądz and Nowy Staw are located in the northern part of present Poland [45-47]. The urban centers selected to test the tool are characterized by a regular spatial layout, typical for cities of the late Middle Ages. They were granted city rights in the years 1246 (old town Elblag), 1291 (Grudziądz) and 1343 (Nowy Staw). In Elblag, instead of a rectangular or square market, there is a functioned widened street, parallel to the waterfront. Nowy Staw, founded under Chełmno law, also has an elongated market square, but the reason for this was the important function of serving the trade of the Vistula delta area. In Grudziądz, we have a layout of a classical Gothic town with an orthogonal spatial layout with a market in the center, in place of one of the quarters. From the 13th and 14th centuries until 1466, the towns and cities were located within the territory of the State of the Teutonic Order in Prussia. They were located under the rule of the Teutonic Order, so they are related not only in terms of chronology (time of foundation), but also territorially.

Figure 2 illustrates the geographical location of the towns analyzed with the HGIS tool. The studied centers are placed both within the present-day and medieval political boundaries.

\subsection{Data Sources}

The research mainly used digitalized city plans and orthophotomaps in various scales (Table 1). The time range of selected cartographic materials is 1710-2020. All cartographic materials were available in the form of reproductions in monographic publications (Nowy Staw) or as digitized source materials collected in the Historical Atlas of Polish Towns (Elblag, Grudziądz), and in the POLONA digital repository (Elblag). A contemporary orthophotomap from the portal mapy.geoportal.gov.pl (Grudziądz), which was also used in this study. The cartographic materials represent the historic center of Elblag and Grudziadz. In the case of Elblag, only the spatial layout of the Old Town was taken into consideration. The New Town area was excluded from the analysis. In Grudziadz, plans covering the area of the medieval town surrounded by walls were selected for analysis. In the case of Nowy Staw, due to its small spatial scale, the archival plans included the area of the entire town, together with its suburbs, and the central area, without the suburbs and the adjacent rural development of Nytyska Wieś. 


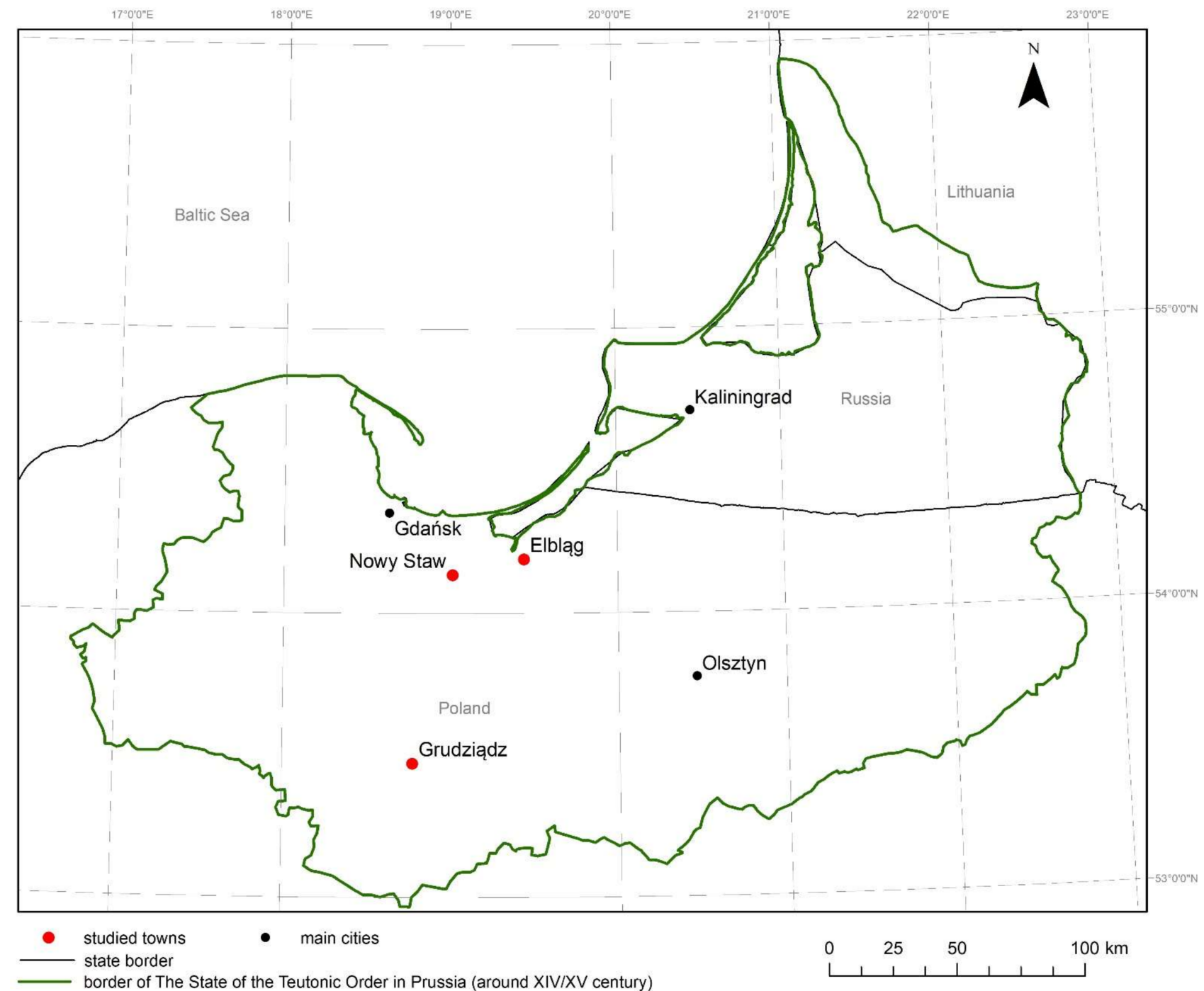

Figure 2. Location of the study area [48].

Table 1. Characteristics of cartographic materials and sources used in the analysis.

\begin{tabular}{|c|c|c|c|c|}
\hline Name & Time Reference & Area & Scale or Resolution & Source \\
\hline Gründ Riss der Stadt Neuteich (Town plan) & 1710 & Historic town area & $1: 3300$ & [49] \\
\hline $\begin{array}{c}\text { Plan von der Königlichen Immediat Stadt } \\
\text { Neuteich (Town plan) }\end{array}$ & $1772-1802$ & Historic town center & $1: 3300$ & [49] \\
\hline $\begin{array}{c}\text { Plan von der Königlichen Immediat Stadt } \\
\text { Neuteich (Town plan) }\end{array}$ & 1802 & Historic town center & 1:3300 & [49] \\
\hline Plan de la Ville d'Elbing (Town plan) & 1774 & Historic Old Town & 1:7000 & [50] \\
\hline $\begin{array}{c}\text { Grundriss der Stadt Graudenz Anno } 1772 \\
\text { (Town plan) }\end{array}$ & 1772 & Historic Old Town & indefinite & [51] \\
\hline Town plan (Grudziądz) & 1897 & Historic Old Town & 1:5000 & [51] \\
\hline Grudziądz (Orthophotomap) & 2020 & Historic Old Town & $1: 2000$ & [52] \\
\hline
\end{tabular}

The historical cartographic materials were spatially georeferenced. Archived plans, not available in digital form, were scanned at a resolution of 400 dpi and saved in *.tif format. Then, using the georeferencing tool available in the ArcMap software, the analyzed material was calibrated. The materials used in the study did not include information about the spatial reference system assigned to them, which would make it possible to perform mathematical operations converting the coordinates of points from one coordinate system to another, calibrating the plans. Therefore, a common orthophotomap was used as a 
reference map, by determining the Ground Control Points (GCP), they were georeferenced in the PL-1992 [6,53] coordinate system currently in use in Poland. Root Mean Square Error (RMS) was used as a measure of the spatial fit quality. RMS values and the number of ground control points are summarized in Table 2. Based on literature findings, it was considered that the achieved accuracies were sufficient for further research [54-56].

Table 2. Characteristics of the quality of spatial matching of source materials, summary of Ground Control Points (GCP) and Root Mean Square Errors (RMS).

\begin{tabular}{cccc}
\hline Name & Time Reference & $\begin{array}{c}\text { Ground Control Points } \\
\text { GCP }\end{array}$ & $\begin{array}{c}\text { Root Mean Square Error } \\
\text { RMS [m] }\end{array}$ \\
\hline Gründ Riss der Stadt Neuteich (Town plan) & 1710 & 31 & 5.7 \\
Plan von der Königlichen Immediat Stadt & $1772-1802$ & 16 & 4.5 \\
Neuteich (Town plan) & 1802 & 27 & 4.7 \\
Plan von der Königlichen Immediat Stadt & 1774 & 30 & 3.7 \\
Neuteich (Town plan) & 1772 & 18 & 2.8 \\
Plan de la Ville d'Elbing (Town plan) & 1897 & 30 & 1.4 \\
Grundriss der Stadt Graudenz Anno 1772 & (Town plan) & & \\
Town plan (Grudziądz) & & & \\
\hline
\end{tabular}

Additionally, in the research, publications and sources concerning the use of square grid methods and the application of the GIS method in historical studies, as well as those describing aspects of the history and metrology of the studied cities, were used.

\subsection{GIS Tools}

Conducting metrological analyses using computer techniques is similar to traditional 'analogue' methods. The primary stage of research involves the determination of measurement modules using a square grid. In the case of GIS tools, this stage has to be preceded by the spatial alignment (georeferencing) of archival cartographic materials. Calibration of the historical map is a vast subject, which has already been discussed at length in the literature [6,18,57-68].

Initially, the square grid for metrological analyses was created using ArcMap 10.7, especially the geoprocessing tools in the ArcToolBox module. Primarily, the Create Fishnet tool available in the Data Management Toolbox, Sampling set, was used. The Create Fishnet tool is available in all versions of ArcMap and in ArcGIS Pro, whereas in the open source software QGIS, there is a tool called "Create grid", which has similar functionality but additionally allows to create diamond and hexagon cell shapes [69]. It was discovered that the functionality of these tools is insufficient to conduct morphometrical research, as it does not allow full customization of the overlaid grid to the required shape and orientation of the polygon study area, which limits their usability, especially in the case of a larger number of analyzed towns plans. The authors used Python programming language to create their own set of tools and added it to the ArcToolbox in ArcMap 10.7. The ArcPy site package was used, as it allows for creating scripts in Python to enable access to geoprocessing tools, as well as additional functions, classes and modules. This allows for significant improvements, even to the more complex data processing. For ease of access, the scripts (tools) were placed in the HGIS Tools box (Supplementary Materials). The set consists of two scripts: HGIS Fishnet and HGIS Fishnet Rhombus.

The first and primary analytical tool used to create a square grid is the Fishnet script. It is based on the CreateFishnet_management (...) function of ArcPy site package, which requires several parameters. The primary innovative function of the HGIS Fishnet tool is the ability to precisely align the grid with the area of study.

The functionality of the script allows the creation of any number of grids with different cell sizes. What is especially important for metrological research is that the grids can be applied to any location of the city plan that serves as a base layer for analyses. The location 
must be defined by the user as rectangular polygon saved in the shape file. This allows for acceleration and significant automation of work, with minimum user requirements. The user has to specify only four parameters: working space-location, where the output layer will be stored, the name of the output layer, the location of the shape file containing the extent of the study area and the cell size (Figure 3). The functionality of this tool is enhanced by adding the ability to choose the cell size from a list that contains medieval distance measures used in the area of study. In addition, the HGIS Fishnet tool allows for differentiating the width and height of the cell size by filling in the 'Multiplicity' field.

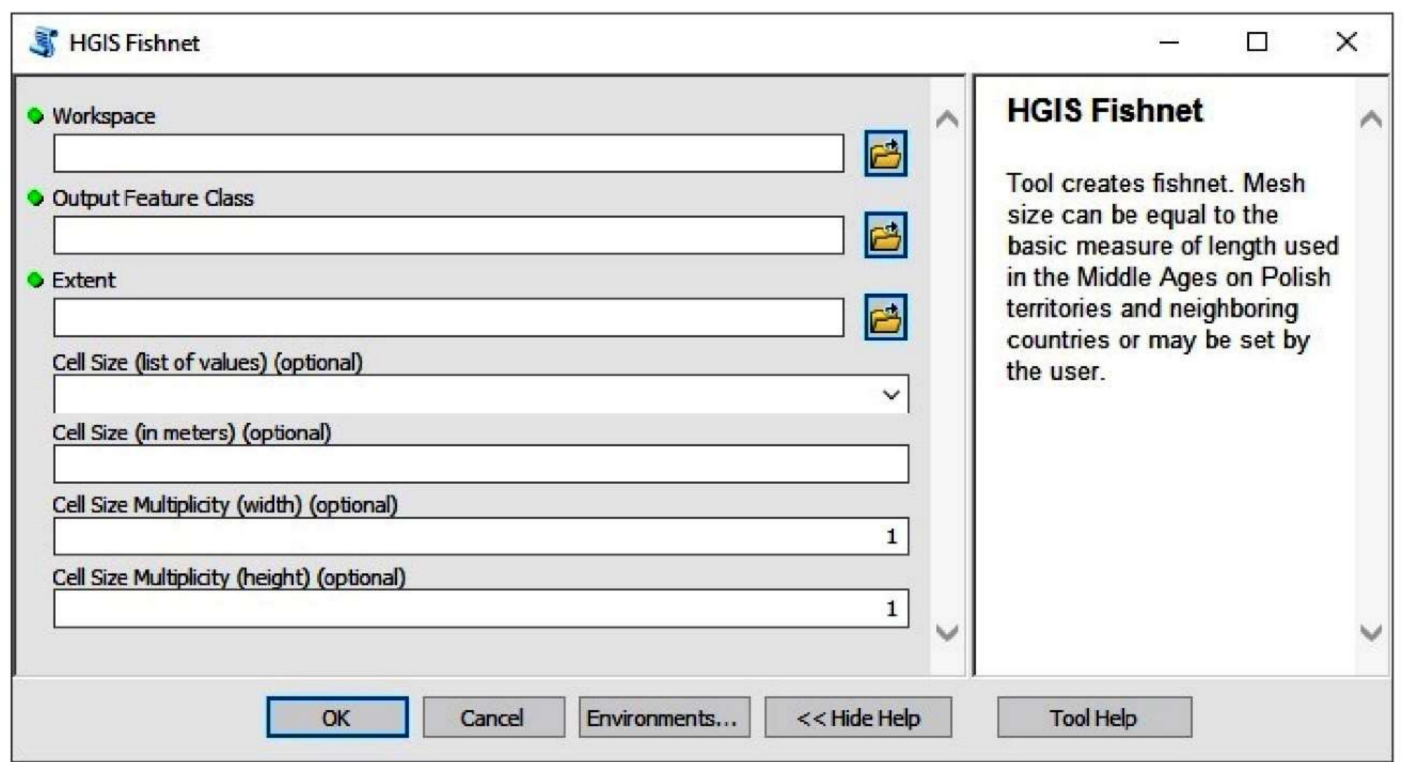

Figure 3. Description of the HGIS Fishnet tool interface [70].

In the next stages of the square grid creation, invisible to the user, a buffer is created around the area of study (Figure 4). The buffer is sized according to the cell gauge, which allows for its later precise alignment to the city plan (base layer) to determine its measurement module. The coordinates of the four end points for the maximum spatial buffer range are then downloaded and used to apply rotation to the grid, in line with the rotation of the area of study. The result is a grid with the chosen cell size and proper rotation, aligned to the extent of study area, expanded by the initially created buffer.

Not all medieval chartered towns were identically measured in space. This could have been caused by an uneven terrain, the course of rivers, an earlier communication system, or the existence of earlier ownership divisions. Therefore, another tool called HGIS Fishnet Rhombus was created to allow for the formation of a grid based on a study area that is not rectangular. HGIS Fishnet Rhombus allows the user to create a rhomboid grid. The principle operation of this tool is different than that of HGIS Fishnet. Grid geometry (angles $\alpha$ and $\beta$ ) (Figure 5) is based on the drawn polygon (tetragon) that includes the study area. The tool uses mainly the UpdateCursor (...) function of the ArcPy site package. The script creates construction lines, parallel to the boundaries of the study area, at intervals defined by the user. The user can choose the cell size from a list or define it directly by entering a value in meters. Then, the construction lines are changed into a grid. A certain limitation of this tool is that the areas of study are of an irregular shape, in some specific cases, the grid may not completely cover the area. However, this problem can be solved by slightly enlarging the polygon that marks the boundaries of the area under investigation. 


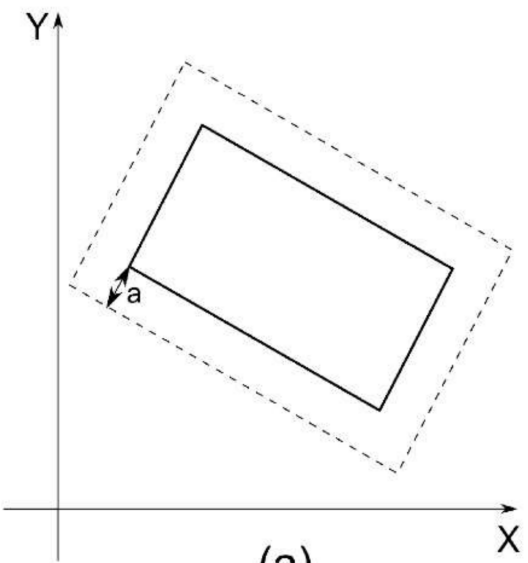

(a)

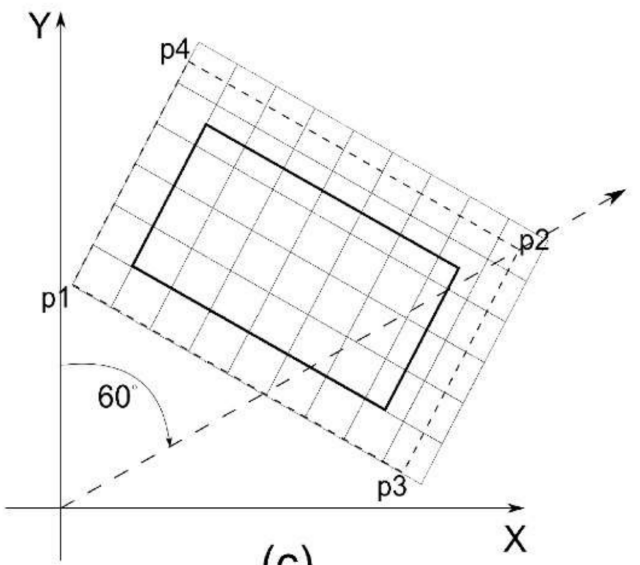

(c)

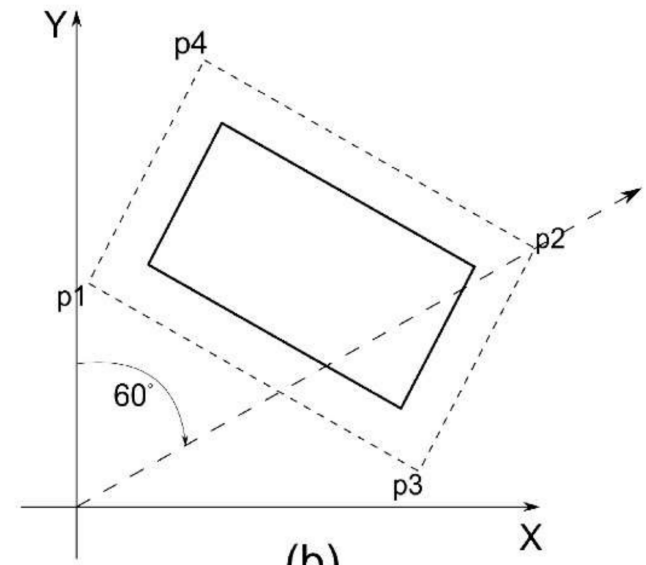

(b)

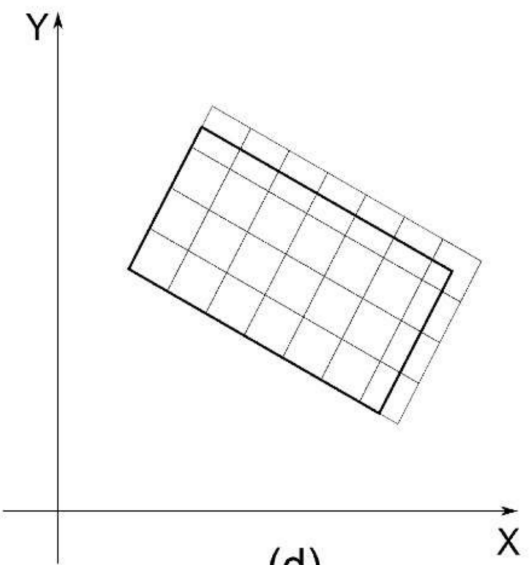

(d)

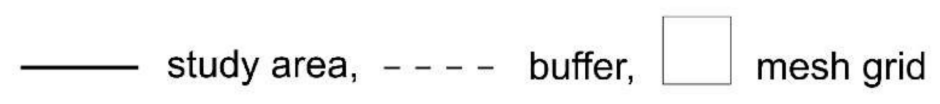

a - size of the mesh grid, p1 - origin point, p2 - Y axis coordinates, p3 - opposite corner coordinates

Figure 4. HGIS Fishnet tool workflow stages: (a) buffering study area, (b) collecting of the four end points of the buffer maximum range coordinates, (c) rotation of the grid in accordance with the study area rotation, (d) trimming of the grid to the extent of the study area.

Although the operation of both tools from the HGIS Tool box is based on the assumptions of the Create Fishnet tool from the Data Management Tools Sampling set, available in ArcToolbox (ArcMap 10.7), significant changes were made. The HGIS Tools enable better matching of the grid to the study area, while reducing the need to specify many parameters by the user. Table 3 presents a comparison of the parameters and functionality of the standard Create Fishnet tool and HGIS Tools. 


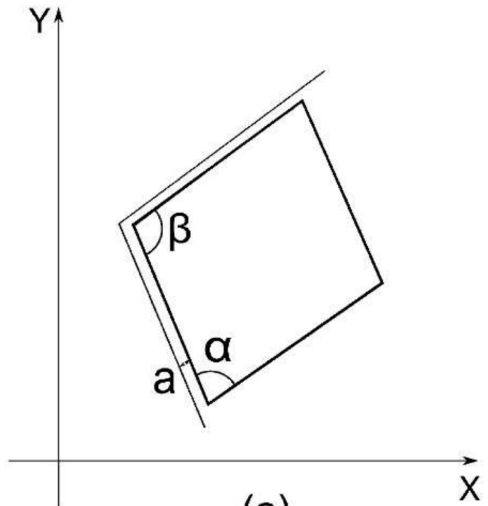

(a)

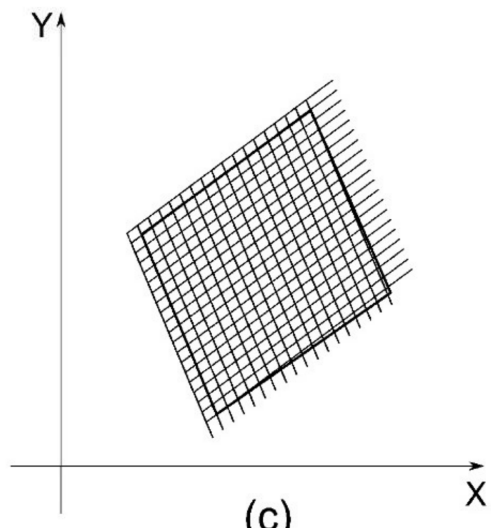

(c)

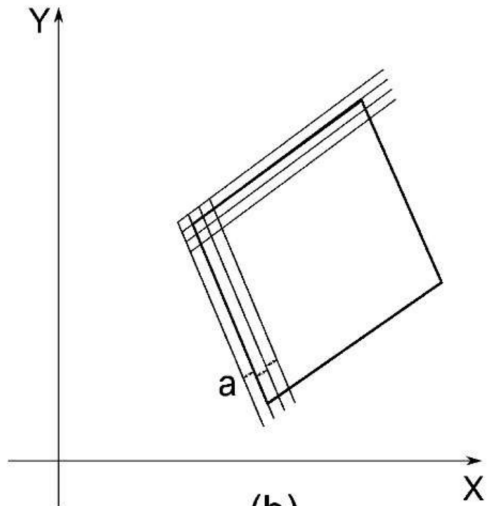

(b)

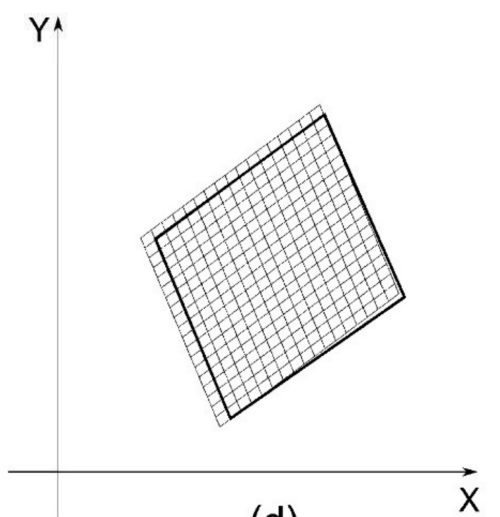

(d)

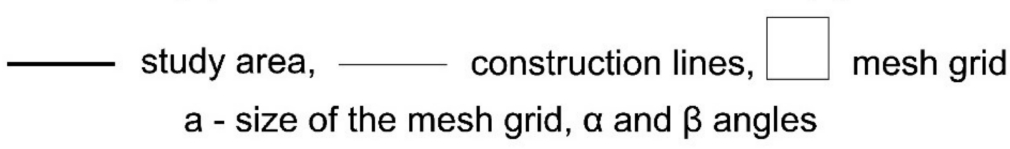

Figure 5. HGIS Fishnet Rhombus tool workflow stages: (a) creating lines referring to the area of study at a distance corresponding to the adopted measure unit and determining the size of the angles of the study area range, (b) copying and shifting horizontal and vertical lines within the range, (c) grid line coverage of the study area, (d) converting the line grid to a polygon grid and trimming of the grid to the extent of the study area.

Table 3. Comparison of the parameters and functionality of the standard Create Fishnet tool (standard ArcToolbox-ArcMap 10.7) and HGIS Tools.

\begin{tabular}{|c|c|c|c|}
\hline Parameter & Description & HGIS Fishnet Tools & Create Fishnet Tools \\
\hline Out feature class & $\begin{array}{l}\text { The output feature class } \\
\text { containing the fishnet of } \\
\text { rectangular cells. }\end{array}$ & $\begin{array}{l}\text { Workspace determined by the user } \\
\text { with the name of the output file } \\
\text { containing fishnet. }\end{array}$ & $\begin{array}{l}\text { Workspace determined by the user } \\
\text { with the name of the output file } \\
\text { containing fishnet. }\end{array}$ \\
\hline Origin coordinates & $\begin{array}{l}\text { The starting pivot point } \\
\text { of the fishnet. }\end{array}$ & $\begin{array}{l}\text { Determined automatically based on } \\
\text { the extent specified by the user in the } \\
{ }^{*} \text {.shp (Extent). }\end{array}$ & $\begin{array}{l}\text { It requires precise coordinates } \\
\text { specified by the user. }\end{array}$ \\
\hline $\mathrm{Y}$ axis coordinates & $\begin{array}{l}\text { The Y-axis coordinate is } \\
\text { used to orient } \\
\text { the fishnet. }\end{array}$ & $\begin{array}{l}\text { Determined automatically based on } \\
\text { the extent specified by the user in the } \\
{ }^{*} \text {.shp (Extent). }\end{array}$ & $\begin{array}{l}\text { It requires precise coordinates } \\
\text { specified by the user. }\end{array}$ \\
\hline Cell width & $\begin{array}{l}\text { Determines the width of } \\
\text { each cell. }\end{array}$ & $\begin{array}{l}\text { Selected by the user from a } \\
\text { drop-down list. }\end{array}$ & $\begin{array}{l}\text { Specified by the user or calculated } \\
\text { based on the number of columns. }\end{array}$ \\
\hline Cell height & $\begin{array}{l}\text { Determines the height of } \\
\text { each cell. }\end{array}$ & $\begin{array}{l}\text { Selected by the user from a } \\
\text { drop-down list. }\end{array}$ & $\begin{array}{l}\text { Specified by the user or calculated } \\
\text { based on the number of rows. }\end{array}$ \\
\hline Number of rows & $\begin{array}{l}\text { Determines the number } \\
\text { of rows the fishnet } \\
\text { will have. }\end{array}$ & $\begin{array}{l}\text { Calculated automatically based on } \\
\text { the cell size. }\end{array}$ & $\begin{array}{l}\text { Specified by the user or calculated } \\
\text { based on the number of cell height. }\end{array}$ \\
\hline
\end{tabular}


Table 3. Cont.

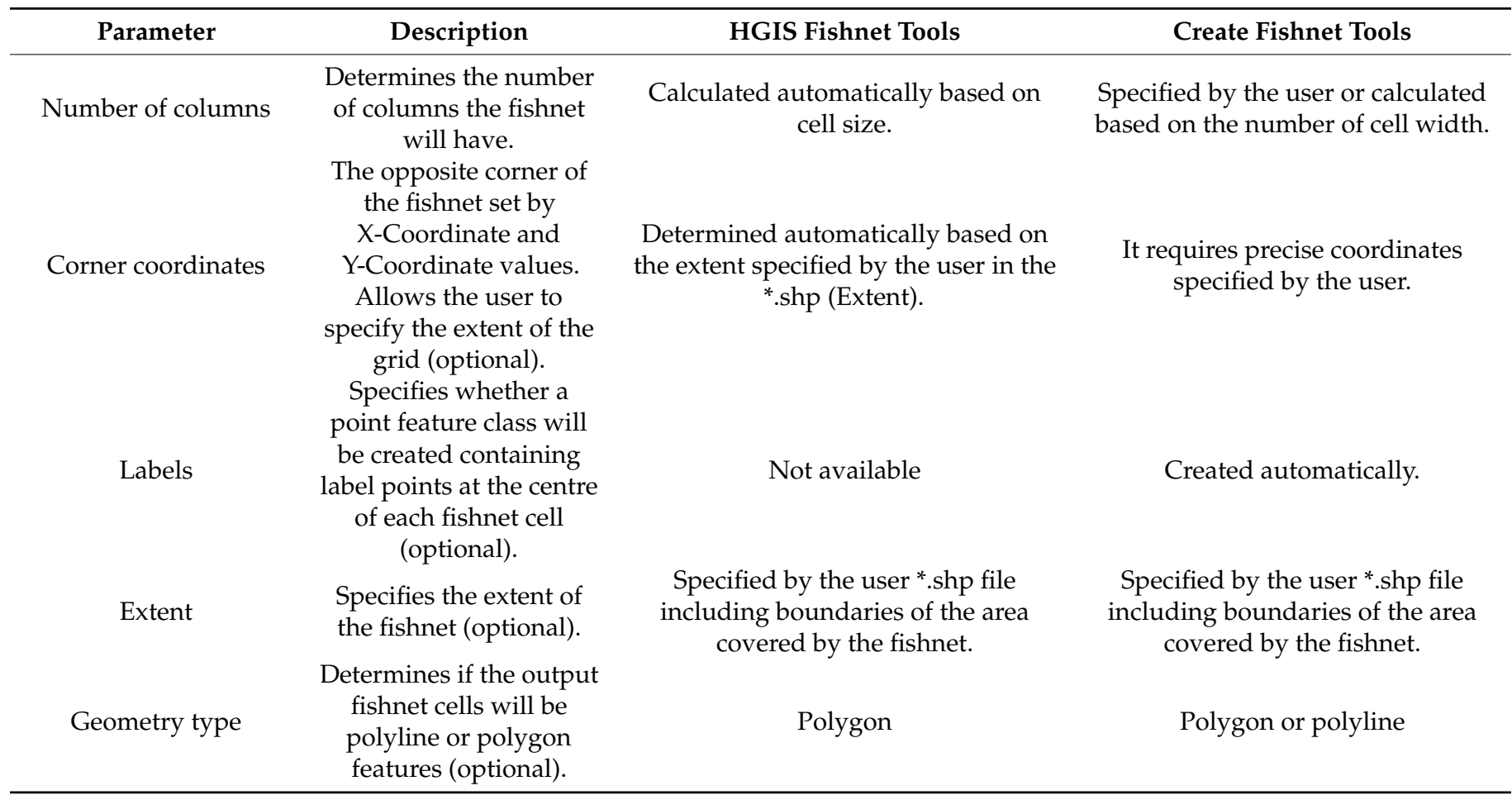

Geospatial approaches for the analysis of historical cartographic material requires their proper preparation and the use of geoprocessing tools. The procedure of preparation of historical cartographic materials for analysis with the use of HGIS tools was summarized in a schematic workflow given in Figure 6.

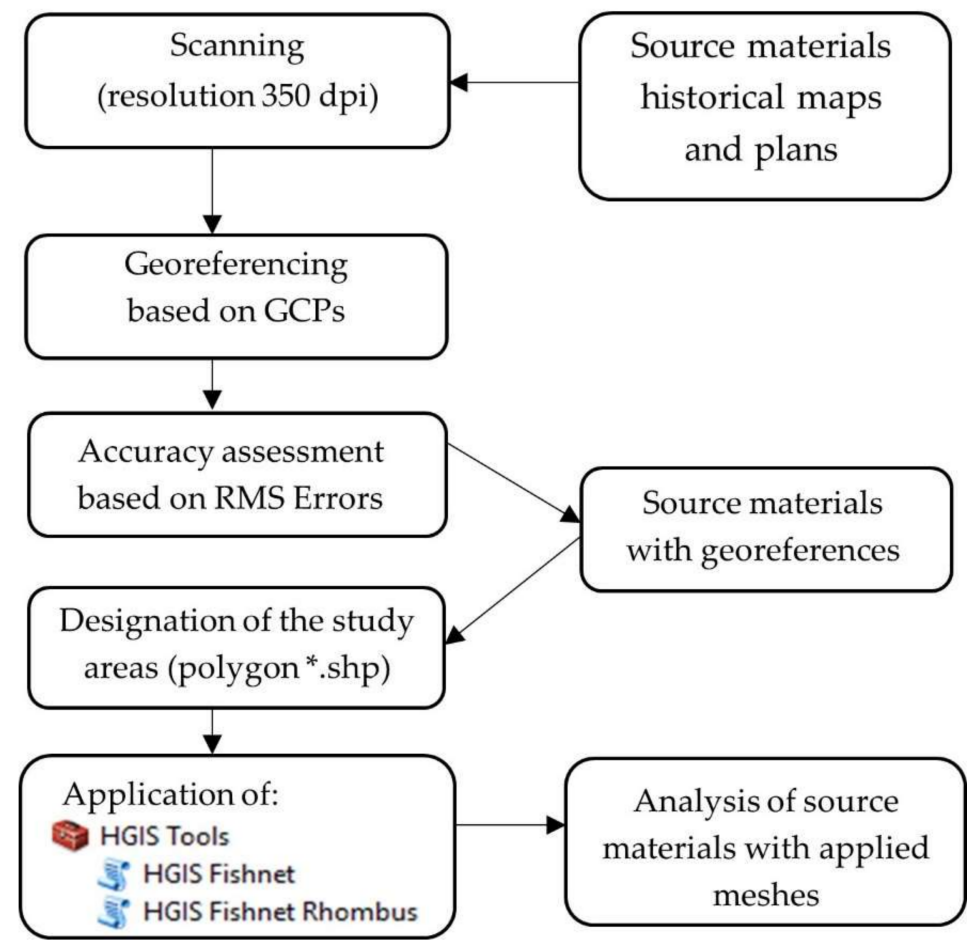

Figure 6. Schematic workflow of preparation of historical cartographic materials for analysis with the use of HGIS tools. 


\section{Results}

The functionality of the HGIS Tool set was presented by overlaying a number of square grids on archival and modern maps of the chosen towns. The examples of towns studied were selected to represent both different morphogenesis, size and importance during the medieval period and today, and to have slightly different features of spatial planning of their old towns. Nowy Staw is characterized by a very elongated town square, whereas Elblag is characterized by a grid layout whose actual layout module, due to the adaptation to local terrain features, is neither square nor rectangular. Finally, Grudziądz represents the typical, fully developed form of a Gothic town with a regular market square. Such a selection of the settlement units allowed for the analysis of various functionalities of the tested tool.

The analysis started with Nowy Staw, a small town in Gdańsk Pomerania, chartered over an earlier village, which was built near a pre-charter settlement. The most likely date of charter made by the Teutonic Knights under Chełmno law is 1343. In the Middle Ages, Żuławy was already a very productive agricultural area, due to the fertile alluvial soil forming the Vistula delta. Its considerable distance from Gdańsk and Elblag did not allow a hike from one's residence to the cities to sell crops and back home in a single day. Hence, there was a need to create a new commercial center to serve local agriculture in the middle of the Vistula delta.

The commercial function of the town is emphasized by its large marketplace, measuring 250 by $45 \mathrm{~m}$ (initially probably $60 \times 10$ rods), which occupied a large portion of the chartered town. The first map, on which a square grid was overlaid, shows Nowy Staw (Neuteich) in 1802 after the fire. Figure 7 shows the process of creating a square grid using the HGIS Fishnet tool. The first step involved the determination of the study area whose shape would resemble the marketplace and include the whole town presented by the map (Figure 7a). Next, the tool was launched, with 1 Chełmno rod, used in Silesia and Pomerania in the 14th century, as the cell size [25]. A buffer equal to the cell size was created around the study area to ensure the inclusion of the whole area in the grid and allow small corrections of its location. Then, a square grid of adopted cell size was created within the buffer (Figure $7 \mathrm{~b}$ ). Additionally, the same tool was used to overlay a second grid, with a cell size 10 times larger than 1 rod, over the study area (Figure $7 \mathrm{c}$ ). The square (cell size) of 10 rods was called 'wężysko' (snakepit). Overlaying two grids over the map allowed for the notation of significant elements of spatial planning, such as the marketplace, an urban block, and the streets (Figure 7d).

This process was repeated for the oldest preserved city plan from 1711. The aim of this operation was to compare the layout and measurement of Nowy Staw before the great fire of 1802 (Figure 8a) and after the regulation of the town following this event (Figure 8b).

An analysis of the oldest preserved plan did not require the recreation of grids and tedious drawing. The digitized and calibrated maps had only to be added to the ArcMap project. By comparing the plans of Nowy Staw from the years 1711 and 1802, it was determined that the earlier plan showed that the layout was not perfectly plotted, so the intended courses of streets, the shape of the marketplace and urban plots was not preserved throughout the existence of the town. This was probably influenced by the local topography, the valley of the Święta river, the existence of Nytyska Wieś that preceded the town, and the pre-charter communication system. As a result of the regulation, the layout of Nowy Staw was cleaned and made more geometric, but the primary elements did not vanish (Figure 8a,b). 


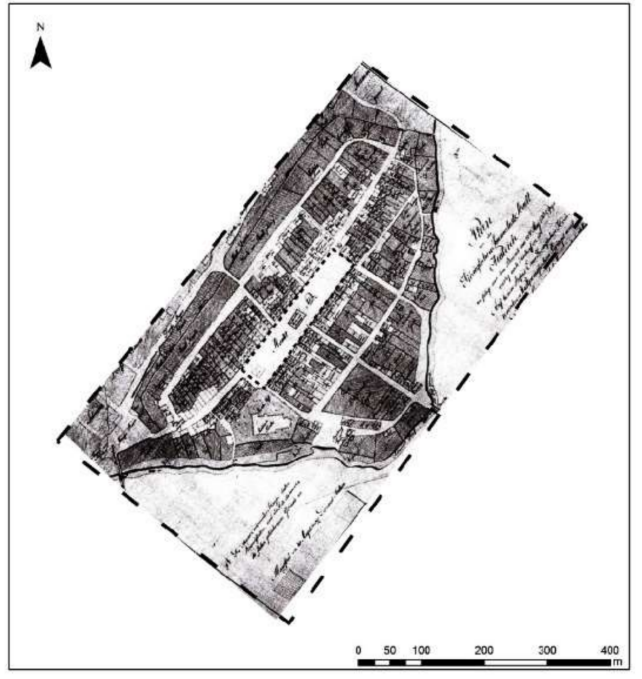

(a)

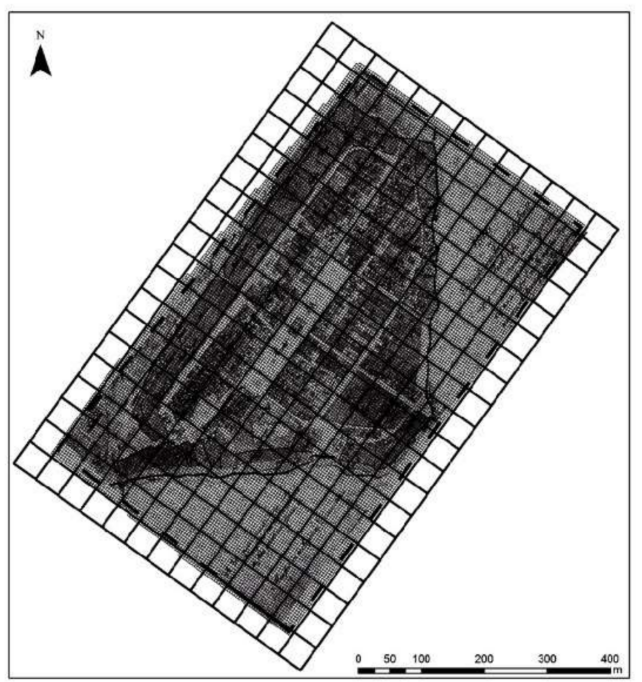

(c)

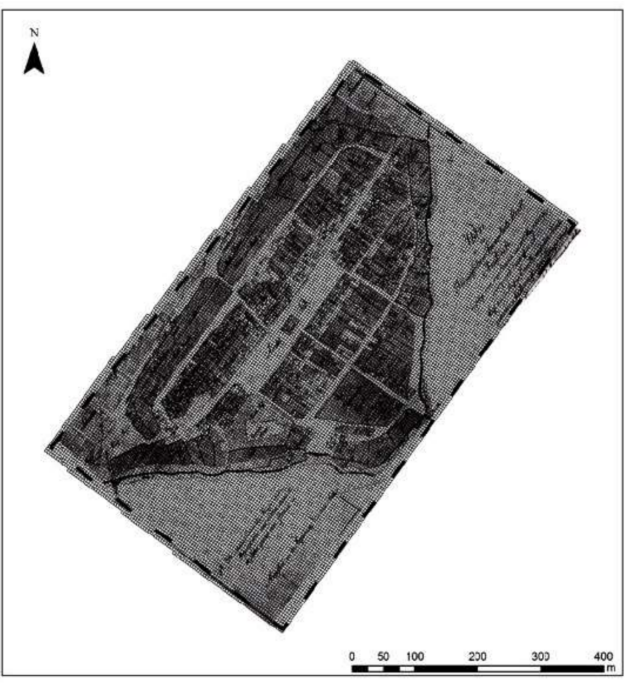

(b)

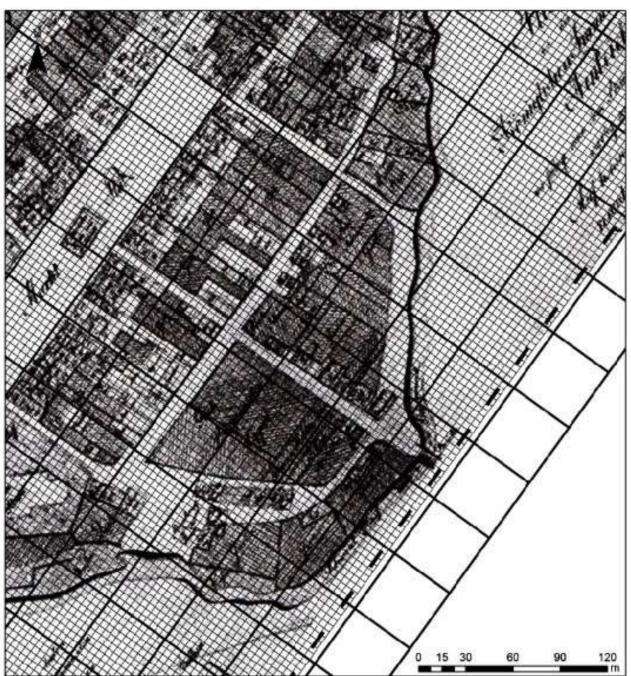

(d)

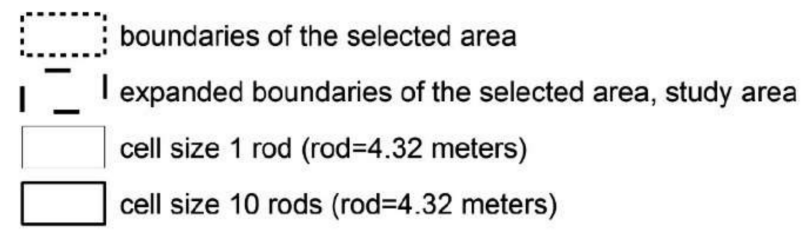

Figure 7. The use of HGIS tools. Example of Plan von der Königlichen Immediat Stadt Neuteich (Town plan) 1802: delimitation of the study area (a), creation of grid (cell size 1 rod) (b), imposition of a modular grid (cell size 10 rods) (c), zoom to the study area and searching for the principles of the modular layout of the city $(\mathbf{d})$. 


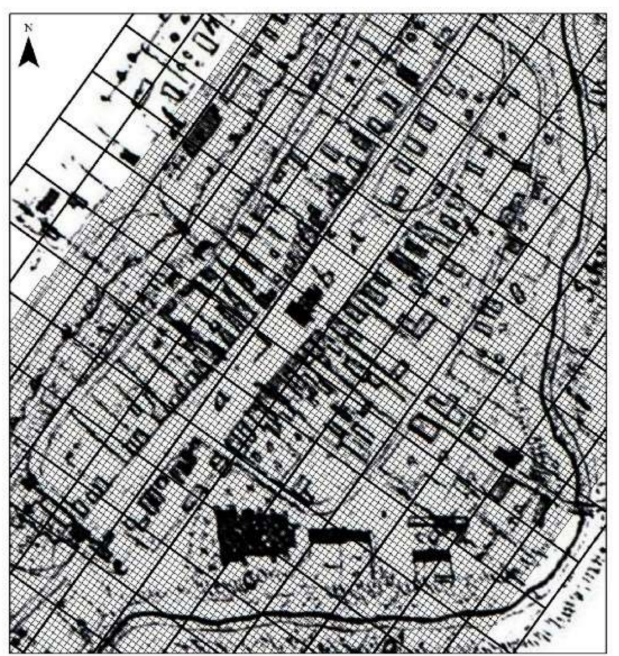

(a)

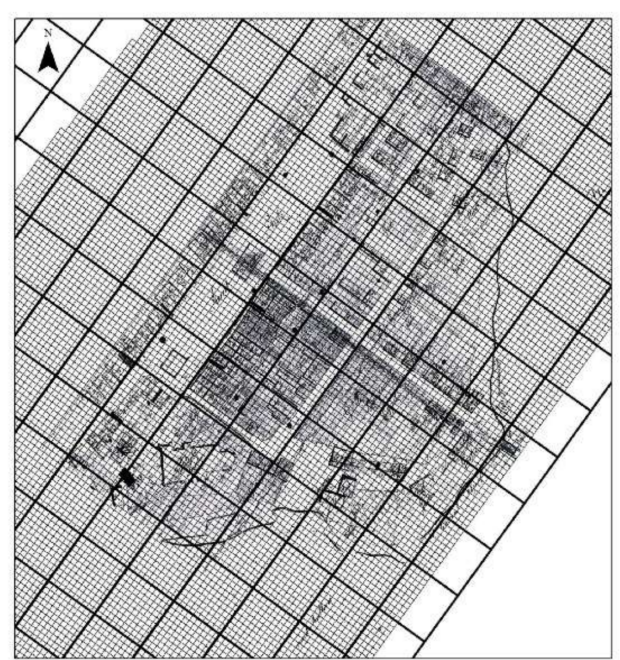

(b)

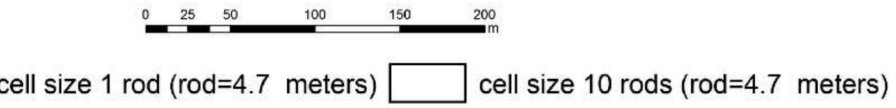

Figure 8. Comparison of the grid created using HGIS Tools for the Gründ Riss der Stadt Neuteich (Town plan) 1710, before the fire of year 1711 (a) and Plan von der Königlichen Immediat Stadt Neuteich (Town plan) 1802, after the regulation of the city (b).

Elblag is an interesting example of an old chartered city. It received the Lübeck law in 1246, which was often given to ports. The spatial layout of such cities, in which the street network was perpendicular or almost perpendicular to the main commercial street or the market square from the port wharf is called a grate layout [24]. Elblag is an interesting example in which the axis of the streets and urban plots is inclined in relation to the primary route at an angle other than 90 degrees. Such a layout of the streets and plots makes using a regular square grid practically useless. The HGIS Fishnet Rhombus tool developed by the authors allowed for plotting a differently shaped grid, namely, a rhombus grid. A comparison of the traditional and new grids is shown in Figure 9. Despite graphical differences between the maps, the analysis of the module measurements has confirmed that a study conducted using GIS tools is similar to the one conducted using traditional methods.

The HGIS Tools square grid method can be successfully applied not only to analyzing archival town plans but also to modern cartographic materials, such as orthophotomaps. This is shown using a series of plans of Grudziadz, founded on the riverside slope of the right bank of the Vistula river (Figure 10). The city was most likely founded in the mid eleventh century, and chartered in 1391 under Chełmno law. To this day, it has preserved much of its initial, regular spatial layout. 


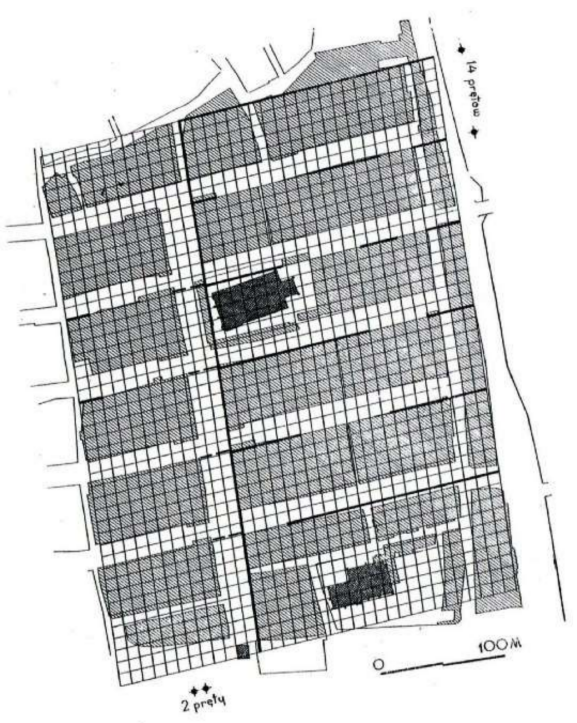

(a)

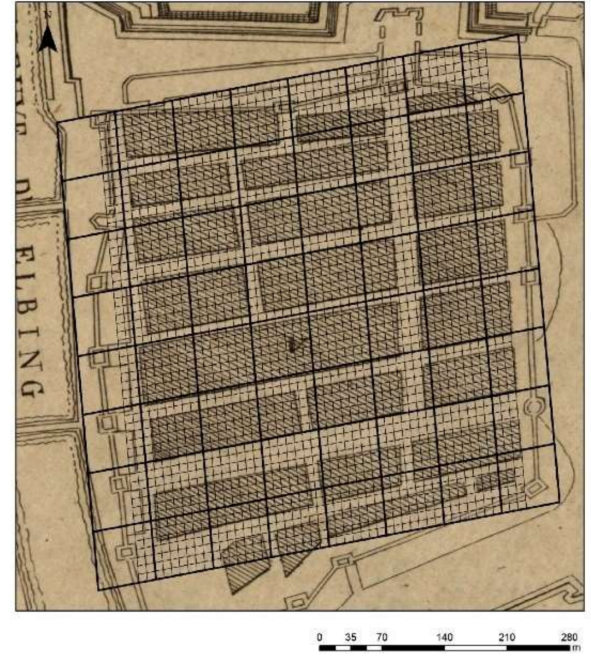

(b)

cell size 2 rods (rod= 4.7 meters) cell size 14 rods (rod=4.7 meters)

Figure 9. Comparison of the research results conducted using traditional method (a) [71] and HGIS tools, example of Plan de la Ville d'Elbing (Town plan) (b).

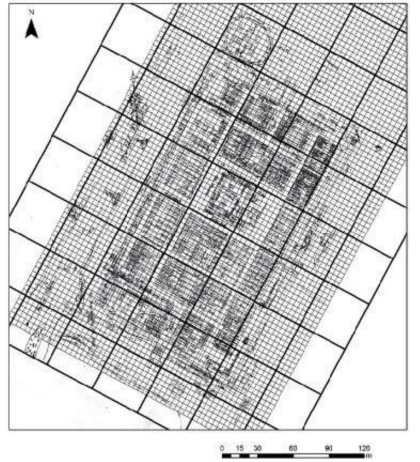

(a)

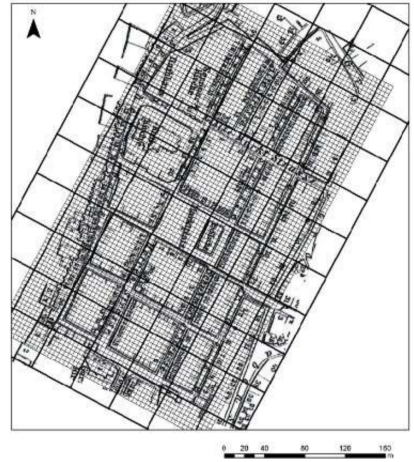

(b)

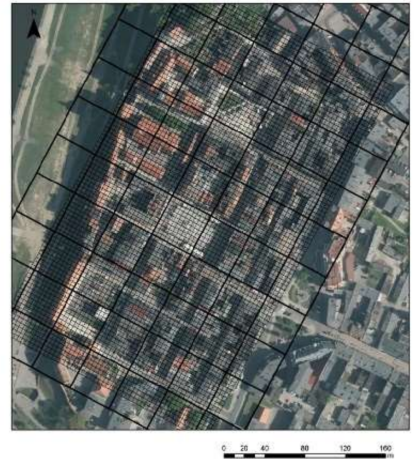

(c)

cell size 1 rod (rod=4.32 meters) $\square$ cell size 10 rods (rod=4.32 meters)

Figure 10. An example of the possibility of applying HGIS tools. Grid imposed on archival Grundriss der Stadt Graudenz Anno 1772 (Town plan) (a), Town plan (Grudziądz) from the year 1897 (b), and a contemporary orthophotomap (c).

\section{Discussion}

The aim of the study was to empirically verify the usefulness of the created tools for the measurement analysis of the historical cartographic materials. The analysis was carried out using the HGIS Tools toolbox. The conducted research confirmed the usefulness of HGIS Tools for generating the grid for morphological and morphometric studies for the example of selected urban centers. Grids of squares are widely used in the analysis of urban areas $[27,35]$. The use of grids of excavation squares is among the basic research tools in archaeology [31]. Various types of square grids are also used in other analyses, such as studies of the spatial development of cities [72-78], cities' landscape change and land use [79-81]. They are also used in studies on urban climate, build-up areas [76,82-85] and on issues related to the quality of life of inhabitants [86,87] or population density [88]. In most of the cases cited, grids were created using GIS tools, including those available in ArcMap software. Not surprisingly, these tools have come into widespread use also on 
HGIS grounds, including urban studies [89]. It should be noted that the progress in the computerization of research processes may facilitate the morphological and morphogenetic studies of urban centers. In recent years, Historical GIS appeared as a new spatial analysis methods, utilizing GIS tools, as well as spatial and historical tools [90]. New technologies allow for improvements of the traditional research methods, introduce brand new data processing methods, and even expand current research perspectives. According to Gregory et al. [91], there are three main benefits of GIS for historical research. Firstly, spatial locations of objects can be used to organize the data and different datasets in various ways. Secondly, data can be visualized in a variety of ways, using conventional maps or different technics. Thirdly, spatial analysis tools can be used to investigate the data. On a larger scale, GIS tools have been used in the study of metrology, urban spatial layouts and archaeology since the early 1990 s $[11,31,35,37,38,92,93]$. The application of GIS in studying the morphology and morphometry of settlements will surely not solve all methodological problems $[5,6,94]$ but may significantly facilitate analyses and create an opportunity to combine different approaches on a common plane.

The biggest advantage of the proposed HGIS Fishnet tool is the ability to easily and quickly adjust the grid cell size to the calibrated town plan, whereas traditional methods force the necessity of drawing separate grids for plans of different scales. The tool also provides custom alignment of the grid to the area of study and the ability to automatically convert historical measurement units to modern ones and vice versa, which is a considerable improvement, compared to the standard ArcToolBox 'Create Fishnet' tool. Additionally, the tool provides ease of comparison and analysis of results for many cities, and the possibility to attach and overlay several historical and modern maps (including Digital Terrain Model—DTM and orthophotomaps) on the map under analysis.

A certain limitation in the use of the HGIS Fishnet tool may be the requirement for proficient use of GIS software. However, the popularity of the use of Geographic Information Systems as research tools allows us to assume that the majority of users will not have problems with its application. A more serious problem seems to be the appearance of errors in the spatial alignment of the historical maps. Maps should be calibrated using control points and the type of geometric correction that ensures the lowest possible Root Mean Square Error (RMS) and deformation. Map calibration distortions can have a significant impact on the performance of the tools because they are unevenly distributed over the map surface [18]. This can make it difficult to size the grid cells proportionally to the size of the distortion. The values of the distortions and their impact are an individual feature of historical cartographic materials resulting from the adopted parameters of calibration. Proper preparation of source materials and taking into account the occurring calibration errors allows for the use of tools and an efficient, time-saving analysis. Another limitation in the use of tools is their incompatibility with software other than ArcMap. The tools do not work with ArcGIS Pro and opensource software, such as QGIS. However, it is possible to develop the tool and adapt it for use in other types of software.

Selected town plans were used to demonstrate the functionality of the new HGIS Fishnet tool. Thanks to the tool, it was possible to confirm information on medieval measurements used in the planning of Elblag and Grudziądz, and to determine probable measurements for Nowy Staw. These results may indicate the utility and usefulness of the developed tool in metrological studies of towns. According to the authors, the HGIS Fishnet tool can be used for the analysis of various regular cities, dating from ancient times to the present. These can be cities from different geographical regions as well as periods of urban development, which have a regular spatial layout $[27,35]$. 


\section{Conclusions}

This paper presents the possible use of the HGIS Tools set developed by the authors for measurement analysis of urban spatial layouts, using the square grid method. The 'Create Fishnet' tool offered in ArcMap 10.7 did not yield satisfactory results, as it did not allow the custom alignment of the grid to the required shape and orientation of the study area, nor the ability to create a slanted grid in which the cell is not regular, but rhombus shaped. For this reason, a new HGIS Tools set was developed. The tools were tested using plans of regular chartered towns from the former monastic State of the Teutonic Order.

An analysis of comparison of features offered by the two methods of square grid plotting showed that the HGIS Tools set allows better functionality and speed. This can be particularly useful when study of a larger number of towns or cities is needed. Any number of grids with the desired cell size may be applied to city plans. A comparison of results of layout and measurement studies using GIS methods should also be considered to be easier and faster. The primary drawback of the tool proposed by the authors is the need to familiarize oneself with the GIS software, even to a minimal extent. Especially important is the knowledge of the editing tools used to create a detailed area of study to be filled with a grid of basic fields.

Quick creation of multiple grids was also tested, as well as their application to any calibrated map in different configurations. The usefulness of these tools is proven by tests conducted on town plans that were already studied using traditional square grids.

In conclusion, it should be noted that the use of traditional methods, as well as the new version of the tool proposed here to create square grids is just one of the elements that support the process of analyzing the layout, measurements and morphology of medieval or any other cities. As mentioned at the beginning of the paper, the methodology used in historical geography, based on analyses of archival town plans, should be confronted with historical sources and verified through archaeological research.

The authors hope that the proposed HGIS Tools will be useful in modern research on urban layout, measurements and morphology. The presented paper is an introduction to further research dedicated to the metrological analysis of a larger group of cities, using the proposed tool.

Supplementary Materials: The following are available online at https: / www.mdpi.com/article/ 10.3390/ijgi10080558/s1. HGIS Tools box form ArcMap 10.7. The set consists of two scripts: HGIS Fishnet (Fishnet regular.py) and HGIS Fishnet Rhombus (Fishnet rhombous.py).

Author Contributions: Conceptualization, Łukasz Musiaka and Marta Nalej; methodology, Łukasz Musiaka and Marta Nalej; software, Marta Nalej; validation, Łukasz Musiaka and Marta Nalej; formal analysis, Łukasz Musiaka and Marta Nalej; investigation, Łukasz Musiaka and Marta Nalej; resources, Łukasz Musiaka and Marta Nalej; data curation, Marta Nalej; writing_original draft preparation, Łukasz Musiaka and Marta Nalej; writing_review and editing, Łukasz Musiaka and Marta Nalej; visualization, Łukasz Musiaka and Marta Nalej; supervision, Marta Nalej; project administration, Łukasz Musiaka; funding acquisition, Łukasz Musiaka and Marta Nalej. Both authors have read and agreed to the published version of the manuscript.

Funding: This research received no external funding.

Institutional Review Board Statement: Not applicable.

Informed Consent Statement: Not applicable.

Data Availability Statement: Publicly available datasets were analyzed in this study. These data can be found here: https:/ / polona.pl/ (accessed on 15 October 2020), http:/ /atlasmiast.umk.pl/ atlasy/grudziadz/ (accessed on 16 October 2020), https://mapy.geoportal.gov.pl (accessed on 10 January 2021).

Acknowledgments: This work was supported by Faculty of Geographical Sciences at University of Lodz.

Conflicts of Interest: The authors declare no conflict of interest. 


\section{References}

1. Boerefijn, W. Designing the Medieval New Town. Urban Morphol. 2000, 4, 49-62.

2. Kropf, K. Morphological Investigations: Cutting into the Substance of Urban Form. Built Environ. 2011, 37, 393-408. [CrossRef]

3. Baker, N. A Characterisation of the Historic Townscape of Central Hereford. Hereford UK Herefordsh. Counc. Herefordsh. Archaeol. Rep. 2010, 266. [CrossRef]

4. Smith, M.E. The Archaeological Study of Neighborhoods and Districts in Ancient Cities. J. Anthropol. Archaeol. 2010, 29, 137-154. [CrossRef]

5. Jenny, B.; Hurni, L. Studying Cartographic Heritage: Analysis and Visualization of Geometric Distortions. Comput. Graph. 2011, 35, 402-411. [CrossRef]

6. Affek, A. Kalibracja Map Historycznych z Zastosowaniem GIS. Pr. Kom. Kraj. Kult. PTG 2012, 16, 48-62.

7. Conzen, M.R.G. The Use of Town Plans in the Study of History. u: The Study of Urban History, New York; St. Martin's Press: Springfield, MO, USA, 1968.

8. Slater, T.R. The Analysis of Burgage Patterns in Medieval Towns. Area 1981, 13, 211-216.

9. McConnachie, M.M.; Shackleton, C.M. Public Green Space Inequality in Small Towns in South Africa. Habitat Int. 2010, 34, 244-248. [CrossRef]

10. Whitehand, J.W.R. British Urban Morphology: The Conzenion Tradition. Urban Morphol. 2001, 5, 103-109.

11. Lilley, K.; Lloyd, C.; Trick, S.; Graham, C. Mapping and Analysing Medieval Built Form Using GPS and GIS. Urban Morphol. 2005, 9, 5-15.

12. Pinho, P.; Oliveira, V. Cartographic Analysis in Urban Morphology. Environ. Plan. B Plan. Des. 2009, 36, 107-127. [CrossRef]

13. Kulesza, M. Conzenian Tradition in Polish Urban Historical Morphology. Eur. Spat. Res. Policy 2014, 21, 133-153. [CrossRef]

14. Terrone, M.; Piana, P.; Paliaga, G.; D'Orazi, M.; Faccini, F. Coupling Historical Maps and LiDAR Data to Identify Man-Made Landforms in Urban Areas. ISPRS Int. J. Geo-Inf. 2021, 10, 349. [CrossRef]

15. Lilley, K.D. Mapping the Medieval City: Plan Analysis and Urban History. Urban Hist. 2000, 27, 5-30. [CrossRef]

16. Kienast, F. Analysis of Historic Landscape Patterns with a Geographical Information System-A Methodological Outline. Landsc. Ecol. 1993, 8, 103-118. [CrossRef]

17. Knowles, A.K.; Hillier, A. Placing History: How Maps, Spatial Data, and GIS Are Changing Historical Scholarship; ESRI, Inc.: Redlands, CA, USA, 2008; ISBN 1589480139.

18. Jaskulski, M.; Łukasiewicz, G.; Nalej, M. Porównanie Metod Transformacji Map Historycznych. Rocz. Geomatyki 2013, 11, 41-57.

19. Skaloš, J.; Weber, M.; Lipský, Z.; Trpáková, I.; Šantrůčková, M.; Uhlířová, L.; Kukla, P. Using Old Military Survey Maps and Orthophotograph Maps to Analyse Long-Term Land Cover Changes-Case Study (Czech Republic). Appl. Geogr. 2011, 31, 426-438. [CrossRef]

20. Kierzkowska-Kalinowska, E.W. Kwestii Badań Nad Rozplanowaniem Miasta Średniowiecznego. Kwart. Hist. Kult. Mater. 1975, 23, 119-122.

21. Vetch, P.; Clarke, C.; Lilley, K. Between Text and Image: Digital Renderings of a Late Medieval City. New Technol. Mediev. Renaiss. Stud. 2011, 3, 365-396.

22. Clack, P.; Haselgrove, C. Approaches to the Urban Past; Council for British Archaeology: York, UK, 1981.

23. Green, A. Introduction: Urban historical archaeology: Challenging ambivalence. In Cities of the World 1500-2000; Green, A.G., Leech, R., Eds.; Taylor \& Francis Group: London, UK, 2006; pp. 1-14.

24. Kulesza, M. Zagadnienia Morfogenezy i Rozplanowania Miast Średniowiecznych w Polsce; Wydawnictwo Ibidem: Stuttgart/Hannover, Germany, 2011.

25. Golachowski, S.; Pudełko, J. O Analizie Metrologiczno-Geometrycznej Planów Osiedli Średniowiecznych. In Kwartalnik Architektury i Urbanistyki: Teoria i Historia; Państwowe Wydawnictwo Naukowe: Warszawa, Polska, 1963; Volume 8.

26. Pudełko, J. Zagadnienie Wielkości i Proporcji Rynków w Badaniach Nad Rozplanowaniem Niektórych Miast Średniowiecznych. Zesz. Nauk. Politech. Wrocławskiej 1960, 36, 25-45.

27. Pant, M.; Funo, S. The Grid and Modular Measures in The Town Planning of Mohenjodaro and Kathmandu Valley A Study on Modular Measures in Block and Plot Divisions in the Planning of Mohenjodaro and Sirkap (Pakistan), and Thimi (Kathmandu Valley). J. Asian Archit. Build. Eng. 2005, 4, 51-59. [CrossRef]

28. Krasnowolski, B. Urbanistyczno-Architektoniczne Przekształcenia Miast Małopolskich Od Doby Lokacyjnej Po Współczesność Jako Wyraz Przeobrażeń Funkcjonalnych. Kult. Polityka 2008, 4, 9-33.

29. Krasnowolski, B. Analiza Modularna Układu Urbanistycznego Jako Klucz Do Odczytania Programu Miasta Lokacyjnego (Na Przykładzie Krakowa z Roku 1257). Archaeol. Hist. Pol. 2015, 23, 259-280. [CrossRef]

30. Malik, R. Działka Lokacyjna w Strukturze Średniowiecznych Miast Małopolskich. XIII-Wieczne Lokacje Miejskie Na Obszarze Dawnego Księstwa Oświęcimsko-Zatorskiego. Wiadomości Konserw. 2012, 31, 68-77.

31. Warner-Smith, A.L. Mapping the GIS Landscape: Introducing “Beyond (within, through) the Grid”. Int. J. Hist. Archaeol. 2020, 24, 767-779. [CrossRef]

32. Wolfe, M. Urban Design Traditions and Innovations in France, 1200-1600. Hist. Mes. 2009, 24, 109-156. [CrossRef]

33. Krasnowolski, B. Wzorce Lokacyjnych Układów Urbanistycznych w Małopolsce: Stan i Metody Badań, Postulaty Badawcze, Próba Syntezy. In Proceedings of the Procesy Lokacyjne Miast w Europie Środkowo-Wschodniej, Wrocław, Poland, 28-29 October 2002; Buśko, C., Goliński, M., Krukiewicz, B., Eds.; Wydawnictwo Uniwersytetu Wrocławskiego: Wrocław, Poland, $2002 ;$ p. 110. 
34. Friedman, D. Florentine New Towns: Urban Design in the Late Middle Ages; Architectural History Foundation Inc.: New York, NY, USA, 1988.

35. Lilley, K.D.; Lloyd, C.D.; Trick, S. Mapping Medieval Townscapes: GIS Applications in Landscape History and Settlement Study. Mediev. Landsc. 2007, 2, 27-42.

36. Smith, M.E. Form and Meaning in the Earliest Cities: A New Approach to Ancient Urban Planning. J. Plan. Hist. 2007, 6, 3-47. [CrossRef]

37. Kvamme, K.L. Recent Directions and Developments in Geographical Information Systems. J. Archaeol. Res. 1999, 7, 153-201. [CrossRef]

38. Gregory, I.N.; Ell, P.S. Breaking the Boundaries: Geographical Approaches to Integrating 200 Years of the Census. J. R. Stat. Soc. Ser. A Stat. Soc. 2005, 168, 419-437. [CrossRef]

39. Gregory, I. The Historical GIS Research Network. Available online: http:/ / www.hgis.org.uk/ (accessed on 10 January 2021).

40. China Historical GIS. Available online: http://www.fas.harvard.edu/ \{\}chgis/ (accessed on 12 January 2021).

41. Dempsey, C. Historical Geography and GIS. Available online: https://www.gislounge.com/historical-geography-and-gis/ (accessed on 12 January 2021).

42. Mapping Medieval Chester. Available online: http://www.medievalchester.ac.uk/ (accessed on 15 October 2020).

43. Atlas Fontium. Available online: https://atlasfontium.pl/ (accessed on 9 September 2020).

44. Jeremicz, J.; Kowalski, Ł.; Kuna, J.; Przystojecki, T. Historyczny Geoportal Lublina (Lublin HGIS). Available online: https: / / teatrnn.pl/bazy-danych/historyczny-geoportal-lublina-lublin-hgis/ (accessed on 9 September 2020).

45. Czacharowski, A. Atlas Historyczny Miast Polskich, Tom 1, Prusy Królewskie i Warmia, Elblag; UMK: Toruń, Poland, 1993.

46. Czacharowski, A. Atlas Historyczny Miast Polskich, Tom 1, Prusy Królewskie i Warmia, Grudziadz; UMK: Toruń, Poland, 1997.

47. Musiaka, Ł. Przemiany Morfologiczne Małego Miasta Na Przykładzie Nowego Stawu. Stud. Geogr. Polit. Hist. 2017, 6, 71-105. [CrossRef]

48. GUGiK Dane Państwowego Zasobu Geodezyjnego i Kartograficznego. Available online: http://www.gugik.gov.pl/pzgik/ (accessed on 15 January 2021).

49. Dirschauer, K. Neuteich in Alten Ansichten. Gesicht Und Geschichte Der Stadt Neuteich. Nowy Staw w Dawnym Spojrzeniu. Oblicze i Historia Nowego Stawu; W\&P: Malbork/Marienburg, Poland, 1999.

50. POLONA. Available online: https:// polona.pl/ (accessed on 15 October 2020).

51. Sieradzan, W.; Kozieł, Z. Atlas Historyczny Miast Polskich. Grudziądz. Available online: http://atlasmiast.umk.pl/atlasy/ grudziadz/ (accessed on 16 October 2020).

52. GUGiK Geoportal Krajowy. Available online: https:/ / mapy.geoportal.gov.pl (accessed on 10 January 2021)

53. Rozporządzenie Rady Ministrów z Dnia 15 Października 2012 r. w Sprawie Państwowego Systemu Odniesień Przestrzennych 2012, Dz.U. 2012 poz. 1247. Available online: http:/ /isap.sejm.gov.pl/isap.nsf/DocDetails.xsp?id=WDU20120001247 (accessed on 17 February 2020).

54. Giętkowski, T.; Zachwatowicz, M. Przemiany Krajobrazu-Czy Można Unikną́ Złudzeń? In Proceedings of the Geograficzne spotkania w drodze. Krok trzeci-Warszawa, Materiały III Konferencji Geografów-Doktorantów, Warszawa, Poland, 10-11 października 2008; Richling, A., Fuhrmann, M., Eds.; WGiSR: Warszawa, Poland, 2010.

55. Wolski, J. Błędy i Niepewność w Procesie Tworzenia Map Numerycznych. Pr. Kom. Kraj. Kult. 2012, 16, 15-32.

56. Zachwatowicz, M. Detekcja Historycznych Przemian Pokrycia Terenu z Zastosowaniem Elementów Logiki Rozmytej. Prace Komisji Krajobrazu Kulturowego 2012, 16, 84-94.

57. Rumsey, D.; Williams, M. Historical maps in GIS. In Past Time, Past Place: GIS for History; Knowles, A.K., Ed.; ESRI Press: Warszawa, Poland, 2002; pp. 1-18.

58. Brigante, R.; Radicioni, F. Georeferencing of Historical Maps: GIS Technology for Urban Analysis. Geogr. Tech. 2014, 9, 10-19.

59. Guerra, F. 2W: New Technologies for the Georeferenced Visualisation of Historic Cartography. Int. Arch. Photogramm. Remote Sens. 2000, 33, 339-346.

60. Bartos-Elekes, Z.; Timár, G.; Imecs, Z.; Magyari-Sáska, Z. Georeferencing the Topographic Map of Walachia (1855-1864). In Proceedings of the 8th International Workshop on Digital Approaches to Cartographic Heritage, Rome, Italy, 19-20 September 2013; pp. 19-20.

61. Timár, G.; Biszak, S. Digitizing and Georeferencing of the Historical Cadastral Maps (1856-1860) of Hungary. In Proceedings of the 5th International Workshop on DIGITAL approaches in Cartographic Heritage, Vienna, Austria, 22-24 February 2010; pp. 559-564.

62. Jaskulski, M.; Nalej, M. Preparing Historical Maps for Presentation in a Geoportal. Acta Univ. Lodz. Folia Geogr. Socio-Oeconomica 2015, 22, 141-159. [CrossRef]

63. Dorobantu, S.; Negrescu, C. The Use of Open Source Solutions in the Process of Georeferencing the Historical Maps. Res. J. Agric. Sci. 2018, 50, 43-50.

64. Baiocchi, V.; Lelo, K.; Milone, M.V.; Mormile, M. Accuracy of Different Georeferencing Strategies on Historical Maps of Rome. Geogr. Tech. 2013, 1, 10-16.

65. Brovelli, M.A.; Minghini, M. Georeferencing Old Maps: A Polynomial-Based Approach for Como Historical Cadastres. e-Perimetron 2012, 7, 97-110. 
66. Affek, A. Georeferencing of Historical Maps Using GIS, as Exemplified by the Austrian Military Surveys of Galicia. Geogr. Pol. 2013, 86, 375-390. [CrossRef]

67. Howe, N.R.; Weinman, J.; Gouwar, J.; Shamji, A. Deformable Part Models for Automatically Georeferencing Historical Map Images. In Proceedings of the 27th ACM SIGSPATIAL International Conference on Advances in Geographic Information Systems, Chicago, IL, USA, 5-8 November 2019; pp. 540-543.

68. Janata, T.; Cajthaml, J. Georeferencing of Multi-Sheet Maps Based on Least Squares with Constraints-First Military Mapping Survey Maps in the Area of Czechia. Appl. Sci. 2021, 11, 299. [CrossRef]

69. QGIS project Documentation for QGIS Testing. Available online: https://docs.qgis.org/testing/en/docs/index.html (accessed on 7 April 2021).

70. ESRI ArcGIS Desktop. Available online: https://desktop.arcgis.com/en/ (accessed on 12 September 2020).

71. Zagrodzki, T. Regularny Plan Miasta Średniowiecznego a Limitacja Miernicza; Ossolineum, Wydawnictwo PAN: Wrocław /Warszawa / Kraków, Poland, 1962; Volume 5.

72. Alghais, N.; Pullar, D. Modelling Future Impacts of Urban Development in Kuwait with the Use of ABM and GIS. Trans. GIS 2018, 22, 20-42. [CrossRef]

73. Wang, H.; Shi, S.; Rao, X. A Study of Urban Density in Shenzhen: The Relationship between Street Morphology, Building Density and Land Use. In Proceedings of the Ninth International Space Syntax Symposium, Seoul, Korea, 31 October-3 November 2013; Kim, Y.O., Park, H.T., Seo, K.W., Eds.; Sejong University Press: Seoul, Korea, 2013.

74. Tan, R.; Liu, Y.; Liu, Y.; He, Q.; Ming, L.; Tang, S. Urban Growth and Its Determinants across the Wuhan Urban Agglomeration, Central China. Habitat Int. 2014, 44, 268-281. [CrossRef]

75. Gandhi, S.R.; Sharma, S.A.; Vyas, A. Quantifying Urban Sprawl for Rajkot City Using Geospatial Technology. Int. J. Built Environ. Sustain. 2016, 3. [CrossRef]

76. Zhou, X.; Okaze, T.; Ren, C.; Cai, M.; Ishida, Y.; Mochida, A. Mapping Local Climate Zones for a Japanese Large City by an Extended Workflow of WUDAPT Level 0 Method. Urban Clim. 2020, 33, 100660. [CrossRef]

77. Li, F.; Zheng, W.; Wang, Y.; Liang, J.; Xie, S.; Guo, S.; Li, X.; Yu, C. Urban Green Space Fragmentation and Urbanization: A Spatiotemporal Perspective. Forests 2019, 10, 333. [CrossRef]

78. Lopez, J.M.R.; Heider, K.; Scheffran, J. Frontiers of Urbanization: Identifying and Explaining Urbanization Hot Spots in the South of Mexico City Using Human and Remote Sensing. Appl. Geogr. 2017, 79, 1-10. [CrossRef]

79. Yang, J.; Guo, A.; Li, Y.; Zhang, Y.; Li, X. Simulation of Landscape Spatial Layout Evolution in Rural-Urban Fringe Areas: A Case Study of Ganjingzi District. GIScience Remote Sens. 2019, 56, 388-405. [CrossRef]

80. Li, J.; Liu, Y.; Pu, R.; Yuan, Q.; Shi, X.; Guo, Q.; Song, X. Coastline and Landscape Changes in Bay Areas Caused by Human Activities: A Comparative Analysis of Xiangshan Bay, China and Tampa Bay, USA. J. Geogr. Sci. 2018, 28, 1127-1151. [CrossRef]

81. Xu, Y.; Wang, L.; Fu, C.; Kosmyna, T. A Fishnet-Constrained Land Use Mix Index Derived from Remotely Sensed Data. Ann. GIS 2017, 23, 303-313. [CrossRef]

82. Estacio, I.; Babaan, J.; Pecson, N.J.; Blanco, A.C.; Escoto, J.E.; Alcantara, C.K. GIS-Based Mapping of Local Climate Zones Using Fuzzy Logic and Cellular Automata. Int. Arch. Photogramm. Remote Sens. Spat. Inf. Sci. 2019, 42, 199-206. [CrossRef]

83. Heris, M.P.; Middel, A.; Muller, B. Impacts of Form and Design Policies on Urban Microclimate: Assessment of Zoning and Design Guideline Choices in Urban Redevelopment Projects. Landsc. Urban Plan. 2020, 202, 103870. [CrossRef]

84. Zhou, X.; Okaze, T.; Ren, C.; Cai, M.; Ishida, Y.; Watanabe, H.; Mochida, A. Evaluation of Urban Heat Islands Using Local Climate Zones and the Influence of Sea-Land Breeze. Sustain. Cities Soc. 2020, 55, 102060. [CrossRef]

85. Guo, G.; Zhou, X.; Wu, Z.; Xiao, R.; Chen, Y. Characterizing the Impact of Urban Morphology Heterogeneity on Land Surface Temperature in Guangzhou, China. Environ. Model. Softw. 2016, 84, 427-439. [CrossRef]

86. Zhao, P.; Hu, H. Geographical Patterns of Traffic Congestion in Growing Megacities: Big Data Analytics from Beijing. Cities 2019, 92, 164-174. [CrossRef]

87. Guo, Y.; Chan, C.H.; Yip, P.S.F. Spatial Variation in Accessibility of Libraries in Hong Kong. Libr. Inf. Sci. Res. 2017, 39, 319-329. [CrossRef]

88. Deichmann, U.; Balk, D.; Yetman, G. Transforming Population Data for Interdisciplinary Usages: From Census to Grid. Washingt. Cent. Int. Earth Sci. Inf. Netw. 2001, 1-20.

89. Pallares-Barbera, M.; Gisbert, M.; Badia, A. Grid Orientation and Natural Ventilation in Cerdà's 1860 Urban Plan for Barcelona. Plan. Perspect. 2020, 719-739. [CrossRef]

90. Gregory, I.N.; Ell, P.S. Historical GIS: Technologies, Methodologies, and Scholarship; Cambridge University Press: Cambridge, UK, 2007; Volume 39, p. 7719. ISBN 1139467719.

91. Gregory, I.N.; Kemp, K.K.; Mostern, R. Geographical Information and Historical Research: Current Progress and Future Directions. Hist. Comput. 2001, 13, 7-23. [CrossRef]

92. Allen, K.M.S.; Green, S.W.; Zubrow, E.B.W. Interpreting Space: GIS and Archaeology; Taylor \& Francis: London, UK, 1990; ISBN 930.10285 161.

93. Gillings, M. Landscape Phenomenology, GIS and the Role of Affordance. J. Archaeol. Method Theory 2012, 19, 601-611. [CrossRef]

94. Knowles, A.K. GIS and History. In Placing History: How Maps, Spatial Data, and GIS Are Changing Historical Scholarship; ESRI, Inc.: Redlands, CA, USA, 2008; pp. 1-13. 